\title{
Influence of Bedding Material on Ammonia Emissions from Cattle Excreta
}

\author{
T. H. Misselbrook ${ }^{1}$ and J. M. Powell ${ }^{2}$ \\ ${ }^{1}$ Institute of Grassland and Environmental Research, North Wyke, Okehampton, Devon EX20 2SB, UK \\ ${ }^{2}$ Agricultural Research Service, USDA, US Dairy Forage Research Center, 1925 Linden Drive West, Madison, 53706
}

\begin{abstract}
Dairy cattle barns are a major source of $\mathrm{NH}_{3}$ emissions to the atmosphere. Previous studies have shown that the bedding material used in the barn can influence the magnitude of $\mathrm{NH}_{3}$ emissions, but little is known about which bedding characteristics are important in this respect. The aims of this study were to assess, at a laboratory scale, the relative importance of the chemical $[\mathrm{pH}$, cation exchange capacity (CEC), C:N] and physical (urine absorbance capacity, bulk density) characteristics of 5 bedding materials (chopped wheat straw, sand, pine shavings, chopped newspaper, chopped corn stalks, and recycled manure solids) on $\mathrm{NH}_{3}$ emissions from dairy cattle urine. Recycled manure solids were the most absorbent of the bedding types ( $4.2 \mathrm{~g}$ of urine/g of bedding), and sand was the least ( $0.3 \mathrm{~g}$ of urine/g of bedding). When beddings were soaked in urine to their absorbance capacities, $\mathrm{NH}_{3}$ emissions over $48 \mathrm{~h}$ (expressed as a proportion of the urine $\mathrm{N}$ absorbed) were not significantly different among bedding types, despite differences in initial bedding $\mathrm{pH}, \mathrm{CEC}$, and $\mathrm{C}: \mathrm{N}$. When equal volumes of urine were applied to equal depths of dry bedding, $\mathrm{NH}_{3}$ emissions over $48 \mathrm{~h}$ were significantly less from sand and pine shavings ( 23 and $42 \%$ of applied urine $\mathrm{N}$, respectively) than from chopped newspaper, chopped corn stalks, and recycled manure solids $(62,68$, and $65 \%$ of applied urine $\mathrm{N}$, respectively), whereas emissions from chopped wheat straw (55\% applied urine N) only differed significantly from that from sand. Differences in the chemical characteristics of the beddings did not explain differences in emission; $\mathrm{NH}_{3}$ emissions increased linearly with CEC contrary to expectations, and there was no significant relationship with initial bedding $\mathrm{pH}$. The physical characteristics of bedding materials were of more importance, as $\mathrm{NH}_{3}$ emissions increased linearly with absorbance capacity and de-
\end{abstract}

Received April 19, 2005.

Accepted August 15, 2005.

Corresponding author: T. H. Misselbrook; e-mail: tom.misselbrook @bbsrc.ac.uk. creased as the bulk density of the packed beddings increased.

(Key words: ammonia emission, bedding material, cattle, urine)

Abbreviation key: $\mathbf{C E C}$ = cation exchange capacity, TAN = total ammoniacal $\mathrm{N}$.

\section{INTRODUCTION}

Agriculture is the major source of $\mathrm{NH}_{3}$ emissions to the atmosphere (Davidson and Mosier, 2004). Concerns about the role of $\mathrm{NH}_{3}$ in the formation of fine particulates (Hughes et al., 2002) and consequent adverse impacts on human health and in the eutrophication and acidification of natural ecosystems (Fangmeier et al., 1994) have led to public and policy pressures to reduce its emission from agricultural sources. In the UK, cattle account for over $50 \%$ of $\mathrm{NH}_{3}$ emissions from agriculture (Misselbrook et al., 2000) and estimates for the US show cattle to be an equally important source (EPA, 2004). Most of the ammoniacal content of manure derives from the labile $\mathrm{N}$ component of urine, predominantly urea, and the rate and extent to which subsequent $\mathrm{NH}_{3}$ emissions occur will depend on a number of chemical and physical factors. Emissions from livestock housing, therefore, may be influenced by interactions between deposited urine and the materials used for livestock bedding. Different cattle housing systems make use of bedding materials in different ways. For example, freestall (cubicle) and tie-stall housing systems may use a limited amount or no bedding at all in the lying areas for the cattle, which would not be intensively fouled by urine and feces. This contrasts with deep litter (bedded pack) systems, where much larger amounts of bedding are used and added to daily and the bedding becomes intensively fouled by excreta.

The presence of bedding material can reduce $\mathrm{NH}_{3}$ emissions from cattle housing; in a controlled comparison experiment, Chambers et al. (2003) reported emissions to be $30 \%$ lower from a straw-bedded, deep litter cattle housing system than from a slurry-based (i.e., free-stall) system. Different bedding materials may influence emissions in a number of ways. First, the physi- 
cal structure of the material may be important, influencing the extent to which urine drains through the bedding. Emissions will be reduced if the urine is protected from air turbulence by a physical bedding layer and the increased diffusion distance for any released $\mathrm{NH}_{3}$ will increase the resistance to gas transfer. This effect is similar to the protective effect of a crop canopy on emissions from slurry placed beneath the canopy as has been shown previously (Sommer et al., 1997; Misselbrook et al., 2002). However, if urine coats the bedding surface, then the increased surface area may lead to an increase in emissions. Second, different bedding materials will have a different capacity to absorb deposited urine. Absorption may reduce emissions by increasing the resistance to gaseous transport. Third, the chemical composition of bedding may influence $\mathrm{NH}_{3}$ emissions in many ways. The $\mathrm{pH}$ and cation exchange capacity (CEC) of the bedding materials may influence the extent to which ammonium ions are held by the bedding (as discussed for ammonium ions in soils by Freney et al., 1983), and the addition of a $\mathrm{C}$ source in the bedding material may promote rapid immobilization of ammoniacal N (Chantigny et al., 2001).

There have been few studies on the influence of bedding materials used in dairy cattle barns on $\mathrm{NH}_{3}$ emissions. Jeppsson (1999) assessed 4 different bedding types for young cattle (long straw, chopped straw with or without an additive, and a chopped straw/peat mixture) and reported emissions to be lowest from the chopped straw/peat mixture. A similar study with pigs housed on a deep litter system gave the same result (Jeppsson, 1998). Andersson (1996) used a laboratory system to assess the influence of a number of strawbased bedding types on $\mathrm{NH}_{3}$ emissions from pig manure and, although not reporting total emissions, stated that emissions were influenced by $\mathrm{C}: \mathrm{N}, \mathrm{C}$ availability, and the physical structure of the beddings used.

The objectives of the present study were to assess, for a wider range of bedding types than previously studied (i.e., chopped straw, sand, pine shavings, chopped newspaper, chopped corn stalks, and recycled manure), 1) the capacity of the beddings to absorb urine; 2 ) the extent to which urine-soaked beddings retained $\mathrm{NH}_{3}$; and 3) the importance of the physical structure of the bedding in reducing $\mathrm{NH}_{3}$ emissions.

\section{MATERIALS AND METHODS}

\section{Bedding Materials}

Six different bedding materials were used in the experiments: chopped wheat straw, sand, pine shavings, chopped newspaper, chopped corn stalks, and recycled dairy manure solids. Wheat straw, a standard bedding used in dairy cow stanchions, and corn stalks, used in heifer free-stall barns, were chopped into approximately 2- to 4-cm lengths using a commercial chopper; newspapers were chopped similarly to give pieces of 2 to $4 \mathrm{~cm}$ in length and width; sand, a standard bedding in free-stall housing, was purchased commercially (particle size in the range of 0.2 to $2.0 \mathrm{~mm}$ in diameter); and dairy manure solids, which were separated from manure liquids using a screw press, were composted and dried. (Dairy manure solids are increasingly being used as bedding on large tie-stall dairy operations.) Bedding materials were analyzed for total $\mathrm{N}$, total $\mathrm{C}$, $\mathrm{pH}$, and CEC. Bedding materials were dried at $100^{\circ} \mathrm{C}$ for $24 \mathrm{~h}$ and ground through a 1-mm screen before total $\mathrm{N}$ and $\mathrm{C}$ analyses by combustion assay (Leco FP-2000 nitrogen analyzer). The $\mathrm{pH}$ of a demineralized water/ bedding mixture (2:1 ratio by weight) was measured using a calibrated portable $\mathrm{pH}$ meter (Accumet AP61, Fisher Scientific). The CEC was determined using a ammonium displacement method (Tucker, 1974). Characteristics of the bedding materials are given in Table 1.

\section{Urine and Feces}

Urine and feces were collected separately from 3 lactating Holstein cows fed a diet consisting of approximately 17\% CP and 26\% NDF using standard components for a lactating dairy cow diet (Broderick, 2003). Urine was collected via indwelling catheter tubes draining into plastic containers embedded in ice, and feces were hand-scraped from metal catchment containers fitted into the tie-stall gutters. Collections took place during September and continued over a period of 100 $\mathrm{h}$, excluding times when the cows were being milked. Composite samples of the urine and feces from the 3 cows were frozen immediately after collection.

The composite urine sample was analyzed in triplicate for $\mathrm{pH}$, total $\mathrm{N}$, total ammoniacal $\mathrm{N}$ (TAN), and urea $\mathrm{N}$ content. Following $\mathrm{pH}$ determination, samples were acidified $\left(60 \mathrm{~mL}\right.$ of $0.07 \mathrm{~N} \mathrm{H}_{2} \mathrm{SO}_{4}$ added to 15 $\mathrm{mL}$ of urine) before subsequent analyses. Total $\mathrm{N}$ was measured by combustion assay (Elementar Vario MAX CN analyzer); $200 \mathrm{mg}$ of sucrose were added to the 2.5$\mathrm{mL}$ urine sample to aid combustion. Total ammoniacal $\mathrm{N}$ content was determined by automated colorimetry (Searle, 1984) following $\mathrm{KCl}$ extraction $(5 \mathrm{~mL}$ of urine in $50 \mathrm{~mL}$ of $2 \mathrm{M} \mathrm{KCl}$, shaken for $2 \mathrm{~h}$, and filtered through Whatman no. 42). Urea $\mathrm{N}$ was determined using an automated colorimetric assay (Broderick and Clayton, 1997) adapted to a flow-injection analyzer (Lachat Instruments, Mequon, WI).

The composite fecal sample was analyzed in triplicate for $\mathrm{pH}$, total N, TAN, and DM content. Dry matter content was determined by drying in an oven to a constant weight at $100^{\circ} \mathrm{C}$. Following $\mathrm{pH}$ determination (of a 
Table 1. Characteristics of the bedding materials used in the study (means of duplicate samples).

\begin{tabular}{lllcrc}
\hline Bedding material & $\mathrm{pH}$ & $\begin{array}{l}\text { Total C } \\
(\mathrm{g} / \mathrm{kg})\end{array}$ & $\begin{array}{l}\text { Total N } \\
(\mathrm{g} / \mathrm{kg})\end{array}$ & $\mathrm{C}: \mathrm{N}$ & $\begin{array}{c}\mathrm{CEC}^{1} \\
\left(\mathrm{cmol}_{\mathrm{C}} / \mathrm{kg}\right)\end{array}$ \\
\hline Chopped straw & 6.9 & 422 & 4 & 105 & 9.7 \\
Sand & 6.0 & 1 & 0 & - & 0.3 \\
Pine shavings & 4.5 & 477 & $<0.4$ & 1344 & 3.8 \\
Chopped newspaper & 6.1 & 429 & 7 & 63 & 8.8 \\
Chopped corn stalks & 6.7 & 430 & 9 & 49 & 9.9 \\
Recycled manure solids & 6.0 & 395 & 33 & 12 & 16.0 \\
\hline
\end{tabular}

${ }^{1} \mathrm{CEC}=$ Cation exchange capacity.

demineralized water/feces mixture, $2: 1$ ratio by weight), acidified samples of feces were freeze-dried and ground for total $\mathrm{N}$ determination by combustion assay (Leco FP-2000 nitrogen analyzer). Total ammoniacal N content was determined by automated colorimetry (Searle, 1984) following $\mathrm{KCl}$ extraction ( $5 \mathrm{~g}$ of feces in $50 \mathrm{~mL}$ of $2 \mathrm{M} \mathrm{KCl}$, shaken for $2 \mathrm{~h}$, and filtered through Whatman no. 42).

\section{Urine Absorbance Measurements}

Bedding materials were oven-dried at $60^{\circ} \mathrm{C}$ overnight and allowed to cool to room temperature. Then, approximately $0.5 \mathrm{~L}$ of each was placed in a 1-L coffee-press canister. The exact weight of the added bedding was recorded. Sufficient urine was added to each canister to cover the bedding material by approximately $2 \mathrm{~cm}$. The canister press screen was lowered to ensure that the bedding material remained below the urine. After being submerged for $4 \mathrm{~h}$, the canisters were placed at a $60^{\circ}$ angle to allow urine to drain from the bedding material, the press screen retaining the bedding material within the canister. Canisters were allowed to drain for $16 \mathrm{~h}$ and then reweighed to determine the amount of urine absorbed by the bedding.

\section{$\mathrm{NH}_{3}$ Emission Measurements}

Two types of $\mathrm{NH}_{3}$ emission experiments were conducted using a system of 6 small laboratory chambers. In the first, emission measurements were made from urine-soaked beddings taken directly from the bedding absorbance measurements to determine the capacity of the different bedding materials to retain the adsorbed $\mathrm{NH}_{3}$. In the second, measurements were made from urine additions to dry bedding materials to assess the influence of the physical structure of the bedding materials on $\mathrm{NH}_{3}$ emissions.

The laboratory chambers used were as described by Misselbrook et al. (2005). Briefly, chambers were constructed from plastic drainage pipe of $10 \mathrm{~cm}$ internal diameter and $19 \mathrm{~cm}$ height. The internal surfaces of the lid were sprayed with a Teflon coating to minimize adsorption of $\mathrm{NH}_{3}$. Each chamber lid had 4 horizontally positioned inlet and outlet ports to ensure good mixing of air within the chamber. The main body of the chamber was filled with cement to simulate a barn floor, leaving a headspace of approximately $350 \mathrm{~mL}$. Chambers were constructed approximately 3 mo before the experiments, and the cement was periodically fouled with feces over that period to encourage development of urease activity, although urease activity was not measured. Air was drawn through the system by means of a vacuum pump; the airflow rate through each chamber was controlled at $4 \mathrm{~L} / \mathrm{min}$. An acid trap (containing $75 \mathrm{~mL}$ of $0.02 \mathrm{M}$ orthophosphoric acid) at the inlet port of each chamber removed any $\mathrm{NH}_{3}$ from inlet air, and a second acid trap at the outlet port of each chamber collected any $\mathrm{NH}_{3}$ emitted during the measurement period. The system was housed in a large incubator such that all experiments were conducted at the same temperature $\left(18^{\circ} \mathrm{C}\right)$.

To determine emissions from the urine-soaked beddings, a subsample of the soaked bedding from each canister was placed into a $\mathrm{NH}_{3}$ emission measurement chamber; the exact weight added to each chamber was recorded. The bedding materials were lightly compacted onto the concrete floor of the chambers to attain a depth of approximately $1.5 \mathrm{~cm}$ and $10 \mathrm{~mL}$ of diluted feces (1:1 demineralized water to wet feces by volume) was immediately added to the bedding in each chamber, applying evenly across the bedding surface, to ensure the presence of the urease enzyme. Emission measurements continued for $48 \mathrm{~h}$ with outlet acid traps being changed after $1,3,6,12,24$, and $32 \mathrm{~h}$.

For measurements from urine applications to dry bedding, $8 \mathrm{~g}$ of feces were first applied evenly to the concrete floor of each chamber. A standard depth (1.5 $\mathrm{cm}$ ) of bedding (dried overnight at $60^{\circ} \mathrm{C}$ ) was added to each chamber, and $10 \mathrm{~mL}$ of diluted feces (1:1 demineralized water to wet feces by volume) were applied evenly across the bedding surface, followed by $20 \mathrm{~mL}$ of urine. Emission measurements continued for $48 \mathrm{~h}$ with outlet acid traps being changed after $1,3,6,12,24$, and $32 \mathrm{~h}$. 
Table 2. Chemical analyses of the urine and feces used in the study (means of triplicate samples).

\begin{tabular}{|c|c|c|c|c|c|}
\hline & $\mathrm{pH}$ & $\mathrm{DM}$ & $\begin{array}{l}\text { Total } \\
\mathrm{N}\end{array}$ & $\begin{array}{l}\text { Total } \\
\text { ammoniacal } \\
\mathrm{N}\end{array}$ & $\begin{array}{l}\text { Urea } \\
\mathrm{N}\end{array}$ \\
\hline & & $(\%)$ & $\longrightarrow$ & $(\mathrm{g} / \mathrm{L})$ & - \\
\hline Urine & 8.1 & $\mathrm{ND}^{1}$ & 7.5 & \multirow{2}{*}{$\begin{array}{l}0.5 \\
(\mathrm{~g} / \mathrm{kg} \text { of } \mathrm{DM}) \\
3.4\end{array}$} & 5.8 \\
\hline Feces & 6.6 & 14.6 & 23.8 & & ND \\
\hline
\end{tabular}

${ }^{1} \mathrm{ND}=$ not determined.

\section{Statistical Analyses}

Three replicate measurements were made of urine absorbance and of $\mathrm{NH}_{3}$ emission from the urine-soaked beddings. Replication was achieved in time; so for each occasion, one bedding treatment was randomly assigned to one of the 6 canisters for urine absorbance measurements, and then the soaked bedding from each canister was randomly assigned to one of the 6 chambers for measurement of $\mathrm{NH}_{3}$ emission. The whole process was repeated on 3 separate occasions, giving 3 replicates for each treatment. Following completion of the urine absorbance and $\mathrm{NH}_{3}$ emission from urinesoaked bedding measurements, 3 replicate measurements (over time) of $\mathrm{NH}_{3}$ emission from urine applied to the dry beddings were conducted; one dry bedding treatment was randomly assigned to one of the 6 chambers for each of the 3 replicate measurement occasions. Data were analyzed by one-way ANOVA, assuming a randomized block design (with measurement occasion as block), using GENSTAT (Lawes Agricultural Trust, 1993) to assess treatment effects on urine absorbance and on cumulative $\mathrm{NH}_{3}$ emission after $48 \mathrm{~h}$ (expressed as $\mathrm{g}$ of $\mathrm{N} / \mathrm{m}^{2}$ and percentage of applied urine N). Simple linear regression analyses were performed (using GENSTAT) to assess the significance of bedding characteristics (initial $\mathrm{pH}, \mathrm{CEC}$, absorbance, C:N, bulk density) on $\mathrm{NH}_{3}$ emissions following urine application to the dry beddings. Data were transformed when distributions deviated from normal (C:N and bulk density).

\section{RESULTS}

\section{Chemical Analyses of Urine and Feces}

Mean analyses of the urine and feces used in the study are shown in Table 2. Urea $\mathrm{N}$ represented $78 \%$ of the total $\mathrm{N}$ content of the urine, which is typical of dairy cattle urine (Bristow et al., 1992).

\section{Urine Absorbance Measurements}

Recycled manure was the most absorbent of the bedding materials, retaining 15 times more urine than sand, the least absorbent, on a weight for weight basis (Table 3). Chopped newspaper was the next most absorbent material, and chopped straw, pine shavings, and chopped corn stalks had similar urine absorbance.

\section{$\mathrm{NH}_{3}$ Emissions from Urine-Soaked Beddings}

As the soaked beddings were added to the chambers to a constant depth, there were significant differences in the mass of each bedding type used depending on the bulk densities of the materials. Thus, a much greater mass of sand was applied than chopped straw, pine shavings, or chopped corn stalks, for example (Table 3). This, together with differences in urine absorbance, resulted in significant differences in the amount of urine $\mathrm{N}$ in each chamber before measurement. The highest amount of urine $\mathrm{N}$ was applied with the recycled manure, followed by sand and chopped newspaper, and the least amount was applied with the chopped straw, pine shavings, and chopped corn stalks (Table 3). In absolute terms, $\mathrm{NH}_{3}$ emission over $48 \mathrm{~h}$ was greatest from the recycled manure treatment and least from the chopped straw, pine shavings, and chopped corn stalks (i.e., the magnitude of $\mathrm{NH}_{3}$ emis-

Table 3. Urine absorbance capacity of different bedding materials and cumulative $\mathrm{NH}_{3}$ emissions over $48 \mathrm{~h}$ from the urine-soaked beddings exposed in the laboratory chambers.

\begin{tabular}{|c|c|c|c|c|c|c|c|}
\hline & $\begin{array}{l}\text { Chopped } \\
\text { straw }\end{array}$ & Sand & $\begin{array}{l}\text { Pine } \\
\text { shavings }\end{array}$ & $\begin{array}{l}\text { Chopped } \\
\text { newspaper }\end{array}$ & $\begin{array}{l}\text { Chopped } \\
\text { corn } \\
\text { stalks }\end{array}$ & $\begin{array}{l}\text { Recycled } \\
\text { manure } \\
\text { solids }\end{array}$ & $\mathrm{SED}^{1}$ \\
\hline Absorbance, $g$ of urine/g of dry bedding & $2.85^{\mathrm{c}}$ & $0.27^{\mathrm{d}}$ & $2.63^{\mathrm{c}}$ & $3.79^{b}$ & $2.77^{\mathrm{c}}$ & $4.22^{\mathrm{a}}$ & 0.15 \\
\hline $\mathrm{NH}_{3}$ emission, $\mathrm{g}$ of $\mathrm{NH}_{3} \mathrm{~N} / \mathrm{m}^{2}$ & $4.7^{\mathrm{c}}$ & $10.9^{b}$ & $7.6^{\mathrm{bc}}$ & $10.0^{\mathrm{b}}$ & $7.7^{\mathrm{bc}}$ & $18.3^{\mathrm{a}}$ & 1.9 \\
\hline $\mathrm{NH}_{3}$ emission, $\%$ of urine $\mathrm{N}$ & 40 & 36 & 55 & 46 & 43 & 50 & 10 \\
\hline $\begin{array}{l}\text { Urine } \mathrm{N} \text { remaining on bedding after } 48 \mathrm{~h} \text {, } \\
\mathrm{mg} / \mathrm{g} \text { of dry bedding }\end{array}$ & $12.8^{\mathrm{a}}$ & $1.3^{\mathrm{b}}$ & $9.2^{\mathrm{a}}$ & $15.6^{\mathrm{a}}$ & $11.6^{\mathrm{a}}$ & $16.2^{\mathrm{a}}$ & 3.2 \\
\hline
\end{tabular}

a,b,c Within rows, mean values with different superscripts differ significantly $(P<0.05)$.

${ }^{1} \mathrm{SED}=$ standard error of the difference of the means.

${ }^{2}$ Calculated from the bedding absorbance values and assuming that no $\mathrm{N}$ was lost before the addition of the bedding to the chamber. 
Table 4. Cumulative $\mathrm{NH}_{3}$ emissions over $48 \mathrm{~h}$ from urine applied to equal depths of dry bedding materials $(\mathrm{n}=3)$.

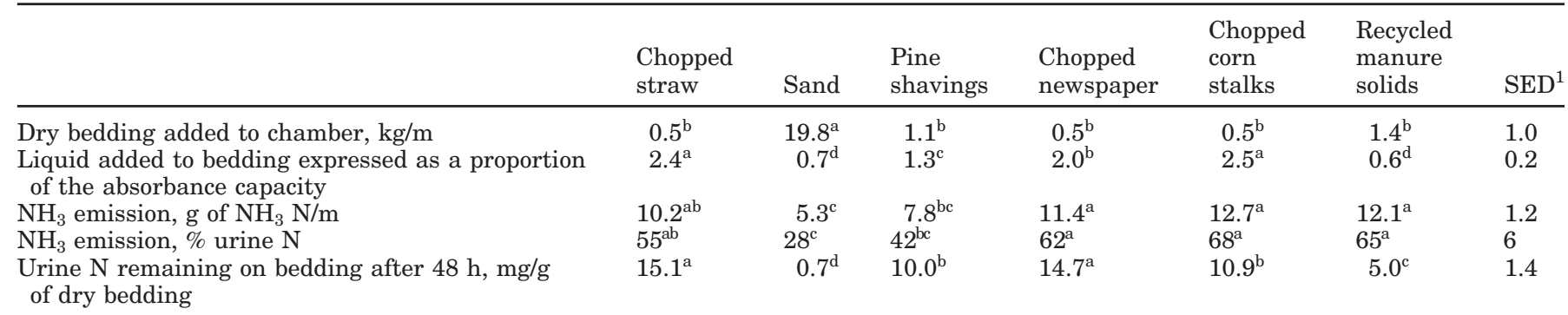

${ }^{\mathrm{a}, \mathrm{b}, \mathrm{c}, \mathrm{d}}$ Within rows, values with different superscripts differ significantly $(P<0.05)$.

${ }^{1} \mathrm{SED}=$ standard error of the difference of the means

sion was related to the amount of urine $\mathrm{N}$ applied) (Table 3). Therefore, when expressed as a percentage of the added urine $\mathrm{N}$, there were no significant differences among bedding types (Table 3 ), and mean emission over $48 \mathrm{~h}$ was $45 \%$ of the added urine $\mathrm{N}$. The calculated $\mathrm{N}$ remaining in the bedding after $48 \mathrm{~h}$, expressed as milligrams of $\mathrm{N}$ per gram of dry bedding, was significantly lower (by a factor of ten) for the sand than for all other treatments.

There was no significant relationship $(P>0.1)$ between $\mathrm{NH}_{3}$ emission (as a percentage of the applied urine $\mathrm{N}$ ) and any of the measured chemical or physical characteristics of the bedding types.

\section{$\mathrm{NH}_{3}$ Emissions from Urine Applied to Dry Beddings}

Equal volumes of dry bedding were added to each chamber, giving significant differences in the mass used (Table 4); the mass of sand was far greater than for the other bedding materials. The volume of urine and diluted feces added exceeded the absorbance capacity of the mass of chopped straw, pine shavings, chopped newspaper, and chopped corn stalks. Emission rates from all treatments, with the exception of sand, increased over the first 12 to $24 \mathrm{~h}$ after urine application; emission rates for chopped straw, pine shavings, and chopped newspaper peaked sooner than those for chopped corn stalks or recycled manure solids (Figure 1). The emission rate from the sand bedding was very much lower than from the other bedding types but, following an initial decrease, continued to increase over the measurement period. Ammonia emissions were least from the sand and pine shavings (Table 4) compared with chopped newspaper, chopped corn stalks, and recycled manure, whereas emission from the chopped straw treatment was not significantly different from either the pine shavings or the chopped newspaper, chopped corn stalks, and recycled manure.

The calculated urine $\mathrm{N}$ remaining in the bedding after $48 \mathrm{~h}$, expressed as milligrams of $\mathrm{N}$ per gram of dry bedding, was significantly lower for the sand, followed by the recycled manure bedding, the 2 treatments which received a volume of urine and diluted feces below their absorbance capacity. For the other treatments, the amount of urine $\mathrm{N}$ remaining in this experiment was similar to those given in Table 3 for the urinesoaked treatments.

There was no significant relationship $(P>0.1)$ between $\mathrm{NH}_{3}$ emission and either the initial $\mathrm{pH}$ or the $\mathrm{C}: \mathrm{N}$ of the bedding types (Figure 2). However, $\mathrm{NH}_{3}$ emission increased with bedding CEC and absorption capacity and decreased with the bulk density of the packed bedding in the chamber. (Figure 2 shows the relationship with the inverse square root-transformed data for bulk density.)

\section{DISCUSSION}

Results from the present study suggest that the physical structure and the relative absorbance capacities of

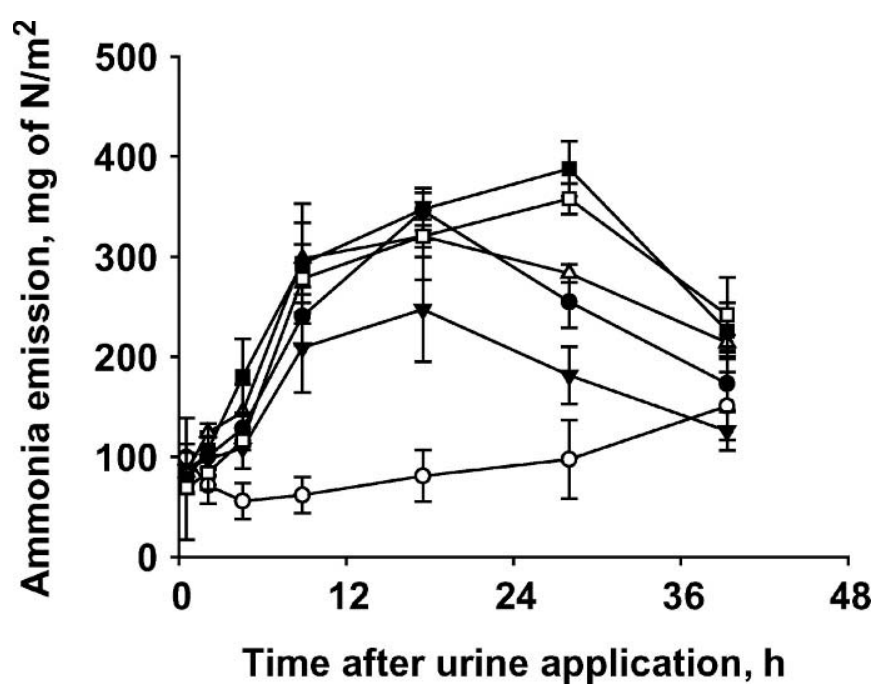

Figure 1. Ammonia emission rates following urine application to different dry bedding materials: chopped straw, $\bullet$; sand, $\bigcirc$; pine shavings, $\mathbf{\nabla}$; chopped newspaper, $\triangle$; chopped corn stalks, $\mathbf{\square}$; recycled manure solids, $\mathbf{\square}$. Error bars show $\pm 1 \mathrm{SE}(\mathrm{n}=3)$. 

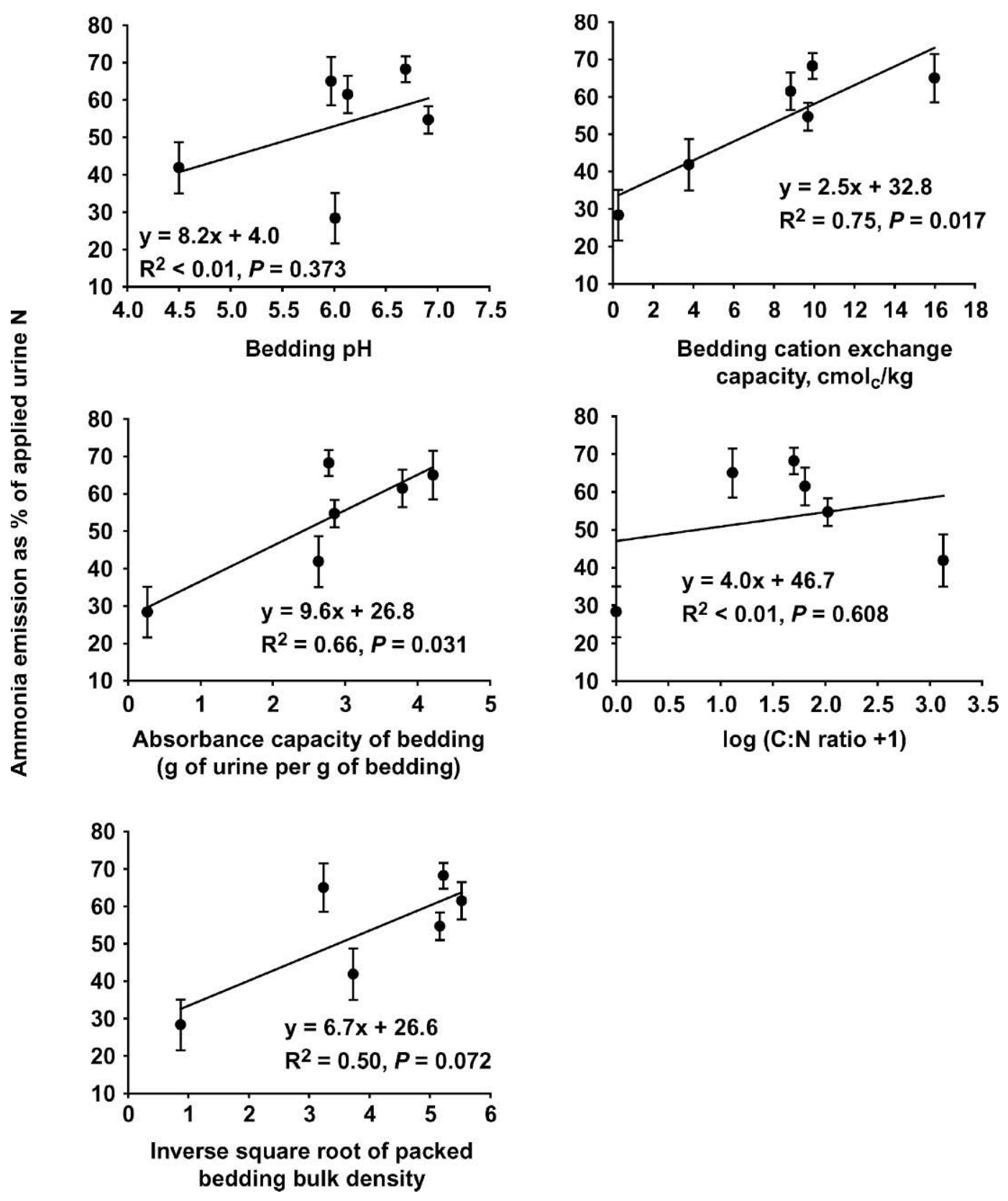

Figure 2. Relationship between ammonia emissions from urine applied to dry beddings and some of the chemical and physical properties of the beddings.

the different bedding types were the most important factors influencing $\mathrm{NH}_{3}$ emission in these laboratory chamber studies. For a given depth of bedding, the loose, open structure of the chopped straw, chopped corn stalks, and chopped newspaper meant that relatively little mass was added; therefore, the mass of urine absorbed was limited. Pine shavings and recycled manure solids were of a slightly higher bulk density, but that of sand was an order of magnitude greater. The volume of urine added to the dry beddings exceeded the absorbance capacity of the less dense materials, and the open structure of the materials increased the surface area coated by urine from which $\mathrm{NH}_{3}$ emission could occur. With the sand, the urine could percolate readily through the material to pool in the bottom layer. Ammonia emission would then be reduced because of the increased resistance to transport as $\mathrm{NH}_{3}$ emitted within the lower sand layer had to diffuse through the upper layers before release into the free air stream. For the recycled manure solids, with the much greater 
absorbance capacity, it is suggested that the majority of the urine was retained in the upper layers with a lower resistance to transport and therefore greater emission.

The chemical properties of the bedding materials (CEC, $\mathrm{pH}$, and $\mathrm{C}: \mathrm{N}$ ) were less important than their physical structure in determining $\mathrm{NH}_{3}$ emissions following urine addition. Emissions from urine-soaked beddings were not significantly different (as a proportion of urine $\mathrm{N}$ added) despite significant differences in the bedding characteristics. When urine was applied to dry beddings in the chambers, there was a significant positive linear relationship between emission and bedding CEC, whereas we might have expected a negative relationship with a greater proportion of ammonium ions being bound to the exchange sites. Equally, we might have expected the more absorbent materials to have lower emissions, but the opposite effect was observed. The lack of any influence of bedding $\mathrm{pH}$ on $\mathrm{NH}_{3}$ emission was probably because of the localized increase in $\mathrm{pH}$ as the urea content of the urine was hydrolyzed; the same effect is given as the reason for a lack of influence of soil $\mathrm{pH}$ on emissions from urea fertilizer applications (Harrison and Webb, 2001).

It is possible that differences in the urease activity of the bedding materials themselves (as opposed to any activity on the cement floor or added feces) might have influenced the $\mathrm{NH}_{3}$ emission rates, although the extent to which urease may have been denatured by drying the beddings overnight at $60^{\circ} \mathrm{C}$ in the present study is unknown as no measurements of urease activity were made. It is known that plant materials produce urease in large amounts (Sirko and Brodzik, 2000), and recycled manure solids might also be expected to contain significant amounts. Therefore, differences in urease activity may offer an alternative explanation (rather than differences in resistance to transport) for the much lower emission observed from the urine applied to dry sand bedding. Elzing and Monteny (1997) showed that $\mathrm{NH}_{3}$ emission rate from urine and feces applied to concrete floors (at $10^{\circ} \mathrm{C}$ and without any bedding material) peaked at about $2 \mathrm{~h}$ after application and declined rapidly thereafter. This result could suggest that urease activity in the present study was limiting, as emission rate peaks were much later and broader (Figure 1), although this equally could have been the physical effect of the bedding materials in increasing the resistance to $\mathrm{NH}_{3}$ transport in the air following urea hydrolysis.

Comparisons of our emission measurements with literature values are difficult to make, both because of a lack of reported studies and differences in the bedding materials used. Jeppsson $(1998,1999)$ reported that a mixture of peat and chopped straw reduced emissions from both pigs and young cattle in bedded pens by approximately 50\% compared with long straw, chopped straw, or wood shavings. Reduction in emissions achieved with the peat/straw mixture were attributed to the high capacity of this bedding to adsorb $\mathrm{NH}_{3}$, a low $\mathrm{pH}$ value, high $\mathrm{C}: \mathrm{N}$, and a high capacity to absorb water. Kemppainen (1987) also showed peat to have a much greater ammonium-binding capacity than long or chopped straw, wood shavings, or sawdust. The recycled manure solids used in the present study might be considered to be physically similar to peat and had the highest absorbance value and CEC of any of the beddings used and a low $\mathrm{pH}$, although it also had a low $\mathrm{C}: \mathrm{N}$. However, in the present study $\mathrm{NH}_{3}$ emissions from the recycled manure treatment were among the highest (Table 4).

It is possible that the other bedding characteristics ( $\mathrm{pH}, \mathrm{C}: \mathrm{N}, \mathrm{CEC}$ ) become more important over the longer term. From Figure 1, it is clear that emissions would have continued beyond the 48-h measurement period. A sigmoid-shaped cumulative emission curve might be expected, with emission rates increasing over the first period as urea hydrolysis proceeds and then declining over the latter period as urea hydrolysis has completed and the pool of ammonium $\mathrm{N}$ becomes depleted. There might have been other treatment differences in $\mathrm{NH}_{3}$ emission if measurements had continued for much longer, but, if $\mathrm{pH}$ and CEC were important factors, it is considered that they would have influenced the emission rates over the first $48 \mathrm{~h}$ from the presoaked bedding treatments.

These results suggest practical applications for bedding used in cattle housing. In terms of urine absorbance, cattle may stay drier on a more absorbent material such as recycled manure solids or chopped newspaper. If low $\mathrm{NH}_{3}$ emission is an important criteria for bedding selection, then it is important that beddings are maintained such that they do not become saturated with urine, as emissions will then be high regardless of bedding type. The results of the present study suggest that $\mathrm{NH}_{3}$ emissions from cattle housed on a bedded pack would increase if the bedding material were changed from sand to straw, but applied to an equal depth (and at a given bulk density). However adding more volume, or a greater mass in the same volume, may overcome some of these differences. In practice, the interaction of urine and feces with bedding in dairy cattle housing may differ from that in the laboratory chambers used in this study. The bedding material will be compacted by the animals, influencing both the absorbance and percolation characteristics. The addition of fresh bedding material on a daily basis will influence emissions from previous urine depositions. Microbial activity within the deeper litter layers may immobilize 
ammonium $\mathrm{N}$ and the $\mathrm{C}: \mathrm{N}$ of the bedding material will become more important in this respect. There would be benefit from future research exploring ways for using each of the bedding materials (accounting for the physical characteristics) to minimize $\mathrm{NH}_{3}$ emissions at a realistic scale, including the animal-bedding interactions. Additionally, an assessment of nitrous oxide emissions and dinitrogen losses (which can be significant from deep litter systems, e.g., Groenestein and Van Faassen, 1996) would highlight any pollution swapping of potential $\mathrm{NH}_{3}$ mitigation strategies.

Choice of bedding material will also depend on a number of other factors, including cow comfort, hygiene, and manure management considerations. Manninen et al. (2002) reported that cows avoided sand bedding, preferring straw or rubber mats, and suggested the poor thermal properties and instability of sand as reasons for avoidance. However, Tucker et al. (2003) showed the importance of preconditioning in such preference studies, reporting that cows previously bedded on straw would prefer straw when given a choice of straw or sand, and those previously on sand would prefer sand. O'Connell and Meaney (1997) reported that cows showed a preference for sawdust over newspaper and that the newspaper bedding required replacing more often, resulting in cost implications. In terms of hygiene, no significant effects on cleanliness or health of stock were noted among sawdust, newspaper, straw, or shavings (O'Connell and Meaney, 1997; Livesey et al., 2003), but Hogan et al. (1989) reported that organic beddings gave increased bacterial counts when compared with inorganic bedding materials (sand or crushed limestone).

\section{CONCLUSIONS}

Bedding materials differed in their capacity to absorb urine; sand was the least absorbent, and recycled manure solids were the most absorbent on a weight for weight basis. Despite differences in the $\mathrm{pH}, \mathrm{CEC}$, and $\mathrm{C}: \mathrm{N}$ of the bedding materials, when soaked in urine to their absorbance capacity, there were no significant differences in the proportion of $\mathrm{NH}_{3}$ being lost through volatilization over a 48 -h period. When urine was applied to dry beddings, emissions over $48 \mathrm{~h}$ were significantly lowest for sand, followed by pine shavings.

\section{ACKNOWLEDGMENTS}

The authors thank K. Niemann (Dairy Forage Research Center) for technical assistance. This work was conducted while T. Misselbrook was a visiting scientist at the Dairy Forage Research Center and was partly supported by the USDA. The Institute of Grassland and
Environmental Research is sponsored by the Biological and Biotechnological Sciences Research Council.

\section{REFERENCES}

Andersson, M. 1996. Performance of bedding materials in affecting ammonia emissions from pig manure. J. Agric. Eng. Res. 65:213-222.

Bristow, A. W., D. C. Whitehead, and J. E. Cockburn. 1992. Nitrogenous constituents in the urine of cattle, sheep and goats. J. Sci. Food Agric. 59:387-394.

Broderick, G. A. 2003. Effects of varying dietary protein and energy levels on the production of lactating dairy cows. J. Dairy Sci. 86:1370-1381.

Broderick, G. A., and M. K. Clayton. 1997. A statistical evaluation of animal and nutritional factors influencing concentrations of milk urea nitrogen. J. Dairy Sci. 80:2964-2971.

Chambers, B. J., J. R. Williams, S. D. Cooke, R. M. Kay, D. R. Chadwick, and S. L. Balsdon. 2003. Ammonia losses from contrasting cattle and pig manure management systems. Pages 19-25 in Agriculture, Waste and the Environment. I. McTaggart and L. Gairns, ed. Scottish Agricultural College, Edinburgh, UK.

Chantigny, M. H., P. Rochette, and D. A. Angers. 2001. Short-term $\mathrm{C}$ and $\mathrm{N}$ dynamics in a soil amended with pig slurry and barley straw: A field experiment. Can. J. Soil Sci. 81:131-137.

Davidson, E. A., and A. R. Mosier. 2004. Controlling losses to air. Pages 251-259 in Controlling Nitrogen Flows and Losses. D. J. Hatch, D. R. Chadwick, S. C. Jarvis, and J. A. Roker, ed. Wageningen Academic Publishers, The Netherlands.

Elzing, A., and G. J. Monteny. 1997. Ammonia emission in a scale model of a dairy-cow house. Trans. ASAE 40:713-720.

EPA. 2004. National emission inventory-Ammonia emissions from animal husbandry operations. Draft Report, United States Environmental Protection Agency, Jan. 30, 2004.

Fangmeier, A., A. Hadwigerfangmeier, L. Vandereerden, and H. J. Jager. 1994. Effects of atmospheric ammonia on vegetation-A review. Environ. Pollut. 86:43-82.

Freney, J. R., J. R. Simpson, and O. T. Denmead. 1983. Volatilisation of ammonia. Pages 1-32 in Gaseous Loss of Nitrogen from PlantSoil Systems. J. R. Freney and J. R. Simpson, ed. Martinus Nijhoff/Dr W Junk, The Hague, The Netherlands.

Groenestein, C. M., and H. G. Van Faassen. 1996. Volatilization of ammonia, nitrous oxide and nitric oxide in deep-litter systems for fattening pigs. J. Agric. Eng. Res. 65:269-274.

Harrison, R., and J. Webb. 2001. A review of the effect of $\mathrm{N}$ fertilizer type on gaseous emissions. Adv. Agron. 73:65-108.

Hogan, J. S., K. L. Smith, K. H. Hoblet, D. A. Todhunter, P. S. Schoenberger, W. D. Hueston, D. E. Pritchard, G. L. Bowman, L. E. Heider, B. L. Brockett, and H. R. Conrad. 1989. Bacterial counts in bedding materials used on nine commercial dairies. J. Dairy Sci. 72:250-258

Hughes, L. S., J. O. Allen, L. G. Salmon, P. R. Mayo, R. J. Johnson, and G. R. Cass. 2002. Evolution of nitrogen species air pollutants along trajectories crossing the Los Angeles area. Environ. Sci. Technol. 36:3928-3935.

Jeppsson, K. H. 1998. Ammonia emission from different deep-litter materials for growing-finishing pigs. Swed. J. Agric. Res. 28:197-206.

Jeppsson, K. H. 1999. Volatilization of ammonia in deep-litter systems with different bedding materials for young cattle. J. Agric. Eng. Res. 73:49-57.

Kemppainen, E. 1987. Ammonia binding-capacity of peat, straw, sawdust and cutter shavings. Ann. Agric. Fenn. 26:89-94.

Lawes Agricultural Trust. 1993. Genstat 5, Release 3 Reference Manual. Oxford University Press, Oxford, UK.

Livesey, C. T., J. A. Metcalf, and R. A. Laven. 2003. Effect of concentrate composition and cubicle bedding on the development of hoof haemorrhages in Holstein heifers after calving. Vet. Rec. 152:735-739.

Manninen, E., A. M. de Passille, J. Rushen, M. Norring, and H. Saloniemi. 2002. Preferences of dairy cows kept in unheated 
buildings for different kind of cubicle flooring. Appl. Anim. Behav. Sci. 75:281-292.

Misselbrook, T. H., T. J. van der Weerden, B. F. Pain, S. C. Jarvis, B. J. Chambers, K. A. Smith, V. R. Phillips, and T. G. M. Demmers. 2000. Ammonia emission factors for UK agriculture. Atmos. Environ. 34:871-880.

Misselbrook, T. H., J. M. Powell, G. A. Broderick, and J. A. Grabber. 2005. Dietary manipulation in dairy cattle-Laboratory experiments to assess the influence on ammonia emissions. J. Dairy Sci. 88:1765-1777.

Misselbrook, T. H., K. A. Smith, R. A. Johnson, and B. F. Pain. 2002. Slurry application techniques to reduce ammonia emissions: Results of some UK field-scale experiments. Biosyst. Eng. 81:313-321.

O'Connell, J. M., and W. J. Meaney. 1997. Comparison of shredded newspaper and sawdust as bedding for dairy cows: Behavioural, clinical and economic parameters. Ir. Vet. J. 50:167-170.
Searle, P. L. 1984. The Berthelot or indophenol reaction and its use in the analytical chemistry of nitrogen-A review. Analyst 109:549-568.

Sirko, A., and R. Brodzik. 2000. Plant ureases: Roles and regulation. Acta Biochim. Pol. 47:1189-1195.

Sommer, S. G., E. Friis, A. Bach, and J. K. Schjorring. 1997. Ammonia volatilization from pig slurry applied with trail hoses or broadspread to winter wheat: Effects of crop developmental stage, microclimate, and leaf ammonia absorption. J. Environ. Qual. 26:1153-1160.

Tucker, B. M. 1974. Laboratory procedures for cation exchange measurements on soils. CSIRO Division of Soils Technical Paper no. 23. CSIRO Australia, Canberra.

Tucker, C. B., D. M. Weary, and D. Fraser. 2003. Effects of three types of free-stall surfaces on preferences and stall usage by dairy cows. J. Dairy Sci. 86:521-529. 